\title{
Dejavnosti in možnosti izoblikovanja jezika na madžarsko govorečem prostoru in proces Palást
}

\author{
Kolláth Anna \\ Univerza v Mariboru, Filozofska fakulteta, Koroška cesta 160, \\ SI-2000 Maribor, anna.kollath@uni-mb.si
}

SCN II/2 [2009], 24-32

V razpravi želim okvirno predstaviti delo, stališča, teoretične vzgibe, dileme in rezultate dela raziskovalne skupine. To temelji na teoriji jezikovnega menedžmenta (Language Management Theory; Björn H. Jernudd in Jiři V. Neustupný), ki poudarja jezikovni problem (in ne jezikovno nepravilnost). Njen cilj je razkrivanje, analiziranje in reševanje čim večjega števila jezikovnih problemov, nastalih $\mathrm{v}$ določenih govornih skupnostih. Jezikovni problem je to, kar občutijo govorci med vsakdanjo komunikacijo, in ne tisto, o čemer odločajo strokovnjaki v različnih elitnih družbenih ustanovah (npr. ministrstva, akademije). Od dosedanje prakse v jezikovni kulturi se strokovnjaki ločimo tudi po tem, da razumemo jezikovne spremembe kot naravne procese in ne kot podiranje knjižne norme. Poudarjamo tudi, da je v okviru madžarske jezikovne skupnosti oblikovanje maternega jezika med manjšinami še bolj pomembno kot v matični državi.

This essay intends to show the results, dilemmas, work, aspects and theoretical motivation behind research group activities underlying language management theory, with the language problem as the focal point (and not language incorrectness). The objective is to uncover, analyse, and solve the most inclusive range of linguistic problems in a language speaking community. The linguistic problem is everything perceived by average speakers in communication, and not problems considered to be such by experts working at certain elite social institutions. It does away with practices of recent language cultivation to an extent that it considers language variations to be a natural linguistic process and by no means a deterioration of the language. It emphasises that language shaping in the language use of minorities inside the Hungarian language community is of even greater importance than in the mother country.

Ključne besede: proces Palást, jezikovna kultura, jezikovno načrtovanje, jezikovni menedžment, jezikovni problem, Prekmurje, madžarski jezik

Key words: process of "Palást", language cultivation, language planning, language management, language problem, Prekmurje, Hungarian language 
Moto: S trianonsko mirovno pogodbo ${ }^{1}$ se je v zgodovini madžarskega jezika končalo obdobje, ko se je madžarski jezik lahko poistovetil s tistim iz Madžarske. »Nove« meje, ki so nastale kot posledica mirovnih pogodb ob koncu prve svetovne vojne, so stopile čez ljudi in skupnosti, s čimer se je v razvoju jezika pričelo novo poglavje. Madžarski materni jezik v Karpatskem bazenu živi, se oblikuje ter spreminja v osmih državah in na osem različnih načinov. Enotnost madžarskega jezika se lahko ohrani le v primeru, če se vseskozi zavedamo, da se madžarsko lahko govori tudi na več načinov. Obstoj zamejskih državnih različic madžarskega jezika moramo sprejeti (kot posledico negativnega usodnega dogodka in rezultat naravnega procesa) kot dejstvo, razlik med njimi pa ne smemo imeti za tragedijo. Oblikovanje različnih, odstopajočih in spremenjenim družbenim razmeram prilagojenih različic madžarskega jezika $\mathrm{v}$ posameznih državah nikakor ne smemo razumeti kot znak, da jezik izumira, pač pa - ravno nasprotno - kot njegovo sposobnost preživetja (Szilágyi 2002).

1 Po spremembi državne ureditve (1990) je tradicionalna (klasična, akademska) jezikovna kultura madžarščine postala predmet strokovnih in znanstvenih razprav. V stališčih, povezanih z jezikovnimi dejavnostmi, se pretakajo številne znanstvene interpretacije in aspekti, posamezna mnenja so se izoblikovala celo na podlagi različnih znanstvenih paradigem. Na konferenci leta 2003, ki jo je organiziral Oddelek za jezikovno kulturo Madžarske akademije znanosti, je postalo jasno, da je dialog med jezikoslovci, ki imajo različna mnenja glede osnov in nalog madžarske jezikovne kulture, potreben in možen. Razmejitev in razčiščevanje odnosa med dejavnostmi, ki se nanašajo na izoblikovanje madžarskega jezika, tj. nujnost obnove jezikovne kulture, je za številne strokovnjake postala očitna med tako imenovanem procesom Palást. Cilj tega procesa je razjasnitev teoretičnih in praktičnih vprašanj jezikovne kulture madžarskega jezika. Ime je dobil po občini Palást na Slovaškem, kjer so leta 2004 organizirali prvo delavnico za uporabno jezikoslovje in kjer so prvič metodično razpravljali o vprašanjih jezikovne kulture. Letno organizirana srečanja so bile skupne prireditve Jezikovne pisarne Gramma iz Dunajske Strede na Slovaškem (Dunaszerdahely) in Jezikovnega inštituta Madžarske akademije znanosti, na njih pa so sodelovali tudi raziskovalci ustanov iz drugih držav; tudi jaz, in sicer kot predstavnica hungaristike s Filozofske fakultete Univerze v Mariboru ter raziskovalka stične različice madžarskega jezika v Sloveniji (v Prekmurju). Material s prvih dveh srečanj je leta 2007 izšel tudi v tiskani obliki (Ágnes DOMONKOSI - István LANSTYÁK - Ildikó POSGAY (ur.), 2007). Odziv stroke je - na osnovi dveh do sedaj objavljenih recenzij - vsekakor pozitiven. Oba recenzenta poudarjata, da delo raziskovalne skupine $\mathrm{v}$ hermenevtični diskusiji

${ }^{1}$ Dne 4. junija 1920 je madžarska vlada z državami antante podpisala trianonsko mirovno pogodbo v dvorcu Veliki Trianon pri Versaillesu v Franciji. Pogodba je določila mirovne pogoje z državami, ki mejijo na Madžarsko. Po tej pogodbi sta Slovaška in podkarpatska Rusija postali del na novo ustanovljene Češkoslovaške republike, Transilvanijo in vzhodni Banat je dobila Romunija, zahodni Banat, Bačka in Prekmurje pa so bili priključeni novi kraljevini SHS. Madžarska je izgubila dve tretjini svojega ozemlja in prebivalstva. To negativno »usodno dejanje« še danes tiči v zavesti in jeziku Madžarov. 
dokazuje, da v tem postmodernem obdobju 21. stoletja moramo in lahko govorimo o teoriji in praksi jezikovne kulture, ki temelji na znanstvenih osnovah.

2 Kot oblikovanje jezika označujemo vse metajezične dejavnosti, cilj katerih je, prvič, bolj ali manj spremeniti pisne in ustne jezikovne diskurze in s tem dolgoročno tudi sam jezik ali posamezne jezikovne različice; drugič pa ustvariti ali razširiti jezik ali določene jezikovne variante na različnih (novih) govornih položajih. Smotrno je ločiti organizirane in neorganizirane/vsakdanje vrste jezikovnega oblikovanja. Organizirane oblike so: jezikovna kultura, jezikovno načrtovanje in jezikovni menedžment. Poglejmo vsakdanje oblike: jezik oblikuje npr. vsakdanji govorec, ki v svojem in sogovornikovem diskurzu popravi resnično ali navidezno napako ali izbere ime otroka. Poleg tega ima tudi odločitev staršev - v kateri program maternega jezika v dvojezičnem šolstvu vpiše svojega otroka - vpliv na oblikovanje jezika. Strokovni izraz oblikovanje jezika ali jezikovno oblikovanje je uporaben, ker je splošen in nevtralen, ne navezuje se na konkretno teorijo in jezikovno oblikovalno smer, zato ga lahko sprejmejo in uporabljajo znanstveniki z različnimi nazori.

2.1 Prvi možni pristop rešitve jezikovnih problemov je torej jezikovna kultura, ki ima v madžarsko govorečem prostoru veliko tradicijo. Nastanek se tesno povezuje z revijo Magyar Nyelvőr Madžarske akademije znanosti (Varuh madžarskega jezika), ki je začela izhajati leta 1872. Pod jezikovno kulturo madžarskega jezika razumem glavno smer madžarske akademske jezikovne kulture, njena dejavnost pa se predstavlja $\mathrm{v}$ reprezentativnih priročnikih in slovarjih. Njen nazor lahko opišem kot enojezičen in preskriptiven, zelo purističen, ki zahteva v vseh govornih položajih jezikovne oblike po eksplicitni normi pisanega knjižnega jezika madžarščine.

2.2 Druga možnost je jezikovno načrtovanje, ki je veliko mlajše od jezikovne kulture, saj je nastalo v šestdesetih, sedemdesetih letih prejšnjega stoletja zaradi rešitve jezikovnih problemov etničnih skupnosti, ki so se osvobodile izpod kolonializacije. Pojem jezikovnega načrtovanja madžarski strokovnjaki zelo dobro poznajo, vendar v praksi manj uporabljajo. Njegov predhodnik je bila madžarska jezikovnoprenovna reforma, ki je potekala med letoma 1772 in 1872. Ta jezikovni proces je težil k politični stabilizaciji nacionalnega jezika kakor tudi h kodifikaciji in k razširitvi jezikovnega standarda. Eden izmed najnovejših programov madžarskega jezikovnega načrtovanja 21. stoletja je t. i. detrianonizacija madžarskega jezika, ${ }^{2}$ ki je hkrati tudi dejavnost deskriptivnega jezikoslovja (http://ht.nytud.hu).

${ }^{2}$ Detrianonizacija madžarskega jezika je program duhovnega, jezikovnega in duševnega prestopanja trianonskih mej, ki so bile začrtane leta 1920. Ta program se je lahko uresničeval šele po političnih spremembah po letu 1990. Je proces jezikovnega združenja (in ne spojitve) zunanjih regij in matične države, ki je postal del skupnega in reflektiranega znanja o jeziku in narodu. Ti procesi so veliko več, saj ne govorijo samo o zbiranju, 
2.3 Tretji pristop je v osemdesetih letih izoblikovan jezikovni menedžment, ki dopolnjuje postopke jezikovnega načrtovanja s teorijo jezikovne korekcije in jih povezuje s teorijo diskurzne analize. Pri reševanju jezikovnih problemov ima naša raziskovalna skupina Palást za najprimernejšo metodo jezikovnega menedžmenta.

3 Teorijo jezikovnega menedžmenta, ki je leta 1970 nastala kot različica nadaljnjega razvoja teorije jezikovnega načrtovanja, pripisujejo Björnu H. Jernuddu in Jiřiju Neustupnýju (Language Management Theory). Predmet jezikovnega načrtovanja niso jezikovne napake, temveč jezikovni problem. Ta se pojavlja v verbalnem sporazumevanju, v konkretnih diskusijah, v njih povzroča dileme, težave, nazadovanja ali pa se k verbalnemu sporazumevanju priključuje na kak drug način, npr. tako, da govorec ne pozna oz. slabo pozna tisto jezikovno različico ali jezik, ki bi ga $v$ določenih situacijah moral uporabljati.

Cilj jezikovnega menedžmenta je čim natančnejše odkrivanje, analiziranje in reševanje jezikovnih problemov v določenih jezikovnih skupnostih. Izhaja iz resničnih težav jezikovne rabe, $v$ tem je njegova realnost. Iztočnica teorije pravi, da je jezikovni problem to, kar ljudje v vsakdanji komunikaciji tako označijo, ne pa tisto, kar označijo v raznih pomembnih družbenih institucijah delujoči strokovnjaki (npr. ministrstvo, akademije).

$\mathrm{V}$ pogledu predmeta jezikovnega oblikovanja jezikovni menedžment močno nasprotuje jezikovni kulturi, katere glavni pojem je jezikovna napaka; to pri nas v praksi razumemo kot odstopanje od kodificirane norme, večinoma neodvisno od jezikovne situacije. Napaka v jezikovni rabi nima skoraj nič skupnega z jezikovno napako, saj je (lahko) jezikovno ustrezna, a uporabljena v neustreznem kontekstu.

Teorija jezikovnega menedžmenta se ukvarja z različnimi jezikovnimi problemi, natančneje z vsemi možnimi. Ne ukvarja se samo z jezikom kot $\mathrm{s}$ sistemom povezanim problemom, temveč tudi z jezikom, nastalim v diskusijah, ukvarja se še s pragmatičnimi vprašanji (npr. vljudnostna vprašanja), s komunikacijskimi vprašanji (s posebnim poudarkom na komunikaciji v medsebojnem sporazumevanju) itd. Veliko pozornost posveča tudi poučevanju jezika in ustvarjanju pravil kot pomembnemu predmetu pri reševanju jezikovnega problema. Velika prednost tega načina je, da probleme opazujejo in rešujejo strokovnjaki kompleksno; to jih vzpodbuja, da ustvarijo pregled nad posameznimi jezikovnimi situacijami.

razjasnjevanju in predstavitvi, ampak tudi o medsebojnem funkcionalnem gibanju besed različnih regij in jezikovnih skupin, o vzpostavitvi prvotnega reda, o okrepitvi jezikovne dinamike med prebivalci Karpatskega bazena z madžarskim maternim jezikom.

$\mathrm{V}$ procesu detrianonizacije ima madžarski jezik - ki s svojimi različicami deluje kot omrežje - po eni strani funkcijo združevanja, po drugi pa funkcijo širitve teh jezikovnih različic. Tako prispeva $\mathrm{k}$ ponovnemu razumevanju in oblikovanju pojma kulturnega naroda (Tolcsvai Nagy 2007: 177). 
Strokovnjaki jezikovnega menedžmenta izhajajo iz običajnih jezikovnih diskurzov vsakdanjih govorcev in raziskujejo jezikovne probleme, ki jih naredijo govorci. Na podlagi tega odločijo, s kakšnimi problemi se mora ukvarjati prirejeno oblikovanje jezika. Pri tem ne misliljo, da njihova dejavnost služi interesom cele govorne skupine ali jezikovne skupine. Vedo, da se posledično iz družbene slojevitosti tudi jezikovni problemi pojavljajo v posameznih družbenih slojih na različne načine, tako tudi rešitve ustrezajo zdaj enemu, zdaj drugemu družbenemu sloju. Pomembno se jim zdi, da je jasno, da njihova dejavnost oblikovanja jezika poteka vedno v interesu kakšnega družbenega sloja. Pri identificiranju jezikovnih problemov izhajajo iz vsakdanjega govorca, večina vsakdanjih govorcev pa ne spada v družbeno elito, zato se lahko predpostavi, da je jezikovni menedžment tisti pristop, ki je od treh navedenih tipov oblikovanja jezika še najbolj namenjen interesu širših družbenih slojev.

4 Prvo tako usmerjeno empirično raziskavo sem opravljala z Istvánom Lanstyákom: anketirali smo enojezične in dvojezične študente madžarščine. Zanimalo nas je, s kakšnimi jezikovnimi težavami/problemi se ubadajo, kako jih poskušajo rešiti, kakšne vrste pomoči dobivajo od strokovnjakov jezikovne kulture ali od jezikoslovcev (Kolláth, Lanstyák 2007). O teoriji teh raziskav samo na kratko. Z metodo spraševanja - čeprav ta ni osnovna raziskovalna metoda jezikovnega menedžmenta - se iz njihovih zavesti lahko prikličejo raznovrstne oblike jezikovnih problemov. Vendar pa nikar ne mislimo, da lahko s to metodo znova in znova, z uvedbo anketirancev iz različnih družbenih ozadij, kadar koli dobimo izčrpni seznam teh jezikovnih problemov. V prihodnosti moramo na vsak način uvesti še druge metode, npr. analizo konkretnih diskurzov.

Med problemi, ki jih omenjajo eno- in dvojezične skupine v raziskavah, so razlike. Npr. ena izmed osrednjih težav enojezične skupine je bila jezikovna sprememba, ki so jo v odgovorih po navadi označili kot podiranje knjižne norme. V nasprotju z njimi so se skupine $\mathrm{z}$ dvojezičnostjo sklicevale bolj na različne aspekte jezikovne pomanjkljivosti.

Jezikovna pomanjkljivost je v osnovi problem govorca: kaže se v pomanjkanju njegove jezikovne kompetence v nekaterih jezikih ali jezikovnih različicah (dialektu, registru). Pomanjkanje jezikovnega znanja je lahko tudi problem jezika, kolikor v jeziku ali v nekaterih njegovih različicah manjkajo takšni elementi ali jezikovne oblike, ki so za govorca potrebne.

V to skupino lahko štejemo vse tiste jezikovne probleme, v katerih se kaže, da sogovorec s standardnim jezikom popravi jezikovno obliko govorca, ga označi, saj s tem onemogoča rabo naravnega, sproščenega jezika (Kontra 2006).

\section{Nekaj konkretnih primerov}

5.1 Prvi jezikovni problem izhaja iz tega, da sogovornik s purističnim nazorom popravi, stigmatizira obliko govornika in s tem ovira naravo jezikovne rabe. Študent, ki se izobražuje v prestolnici, je bil po telefonskem pogovoru glede 
lektorskih vaj s tamkajšnjim lektorjem madžarščine kategorično popravljen, ker je en glagol uporabil v pogovorni/narečni obliki. Sprva je bil študent presenečen, nato zgrožen (sogovorca se nista poznala) in še v tistem trenutku se je odločil, da niti ne bo šel na dogovorjeni razgovor, ampak bo obiskoval lektorske ure na drugi fakulteti.

5.2 Z drugim primerom bi želela predstaviti, kako učinkovita je lahko naša preskriptivna jezikovna kultura. Pridevniško obliko geografskih imen (zloženk), ki imajo v drugem delu - falu (vas - vaški), uporabljajo v vseh jezikovnih položajih v Prekmurju v narečni obliki - falusi: npr. hosszufalusi, völgyifalusi (dolgovaški, dolinski). Danes se v časopisu že brez izjem pojavlja standardna jezikovna oblika teh izrazov, in sicer hosszúfalui, völgyifalui (brez-s-ja). Poučna pa je njegova fleksibilna raba v govoru. Naslednjo situacijo sem doživela sama: ob otvoritvi prireditve v Dolgi vasi - torej v uradnem govornem položaju - je ravnatelj pozdravil dolgovaške goste (hosszúfalui) po standardu, malo kasneje pa je govoril o svojem dolgovaškem poreklu ter na tem mestu rekel: »Jaz sem tudi dolgovaški« (hosszufalusi vagyok). Tu se vidi, kako tesno sta povezani jezikovna situacija in tema $\mathrm{z}$ izbiro jezikovne različice. $\mathrm{V}$ tem primeru moramo poleg refleksa izpostaviti čustveno navezanost na vernakularno jezikovno obliko govorca, ki preprečuje, da madžarska standardna oblika prevlada nad vernakularno obliko. Z našimi jezikovnimi nasveti problema nismo mogli rešiti, ampak smo govorca glede uporaba materinščine celo spravili v dvom.

V zborniku o jezikovni kulturi madžarščine v Prekmurju József Varga (2003: 23) o tem notranjem jezikovnem vprašanju piše naslednje:

Pred nekaj leti sem tudi sam namesto pripone $-i$ uporabljal obliko -si, to pomeni, da sem namesto visoke, standardne oblike vedno izgovarjal in pisal ljudsko/narečno varianto. Moji kolegi iz Madžarske so me opozorili, da je to po standardni normi madžarščine napačno. Od takrat uporabljam le standardno obliko.

Moja diplomantka, ki je iz Doline pri Lendavi (je torej völgyifalusi), je ta jezikovni problem interpretirala tako (Horvat 2001: 45):

Po mojem mnenju moramo sprejeti narečno/vernakularno obliko - v neformalnih situacijah za vsako ceno -, pustimo jo torej pri miru, ker je to kot osebno ime nekoga. Do zdaj sem bila prepričana, da sem völgyifalusi, zdaj pa lahko povsod berem in slišim, da v mojem rojstnem kraju živijo völgyifalui ljudje. Občutek imam, kot da bi dvomili o mojem obstoju.

Jezikovnega problema govorca s svojim jezikovnimi nasveti nismo rešili, temveč smo v govorčevi uporabi jezika povzročili negotovost in motnjo.

5.3 V naslednjem primeru se kaže tesna povezava avtomatizacije, torej instinktivne uporabe jezika ali jezikovne različice s komunikacijsko situacijo. Študent četrtega letnika je opravil pisni izpit pri predmetu Jezikovna kultura. V izpitni poli je vzorno popravil končnico prislovnega določila stavka tako, kakor zahteva pravilo madžarske akademske jezikovne kulture (namesto kontaktne variante, 
kalka, dobesednega prevoda iz slovenščine (németnél - pri nemščini) je napisal standardno varianto (németböl — *iz nemščine). Profesor se je veselil, imel je občutek, da je uspel. Po vpisu ocene pa se je študent poslovil z besedami: »Mudi se mi, ker mi mora profesor tudi pri geografiji (földrajznál) vpisati oceno.«

5.4 Na dvojezičnem območju so konec oktobra leta 2008 postavili spomenik v spomin na prisilno izseljene vaščane po drugi svetovni vojni. Na spomeniku v obeh jezikih piše: A kilakutatottak emlékére. V madžarski povedi se beseda izseljenci (po normi madžarskega knjižnega jezika: kilakoltatottak) pojavi v lokalnem narečju (- $l$ na koncu zloga izpade $\mathrm{v}$ govoru in $-o$ - pred $-l$-jem bo $-u$ ). Jezikovni pojav - da se dve jezikovni normi križata, knjižna ter narečna - je pri nekaterih ljudeh vzbudil pozornost, večina pa se je razburila in ni sprejela dialektalne variante te besede. Nastala je diskusija o pravilnosti oz. nepravilnosti tega. Večina je mnenja, da to ni prav, da tako ne bi smelo biti napisano, da je to napaka, ki bo ostala za vedno. $\mathrm{S}$ tem je skupina stigmatizirala samo sebe, saj je svoj vernakular uporabila na neprimernem mestu.

Vprašanje pa bi postavila tako: Ali je ta narečna beseda takrat in tam (tukaj in zdaj), v tem formalnem kontekstu, v tem vzvišenem stilu primerna ali neprimerna? Menim, da so naročniki spomenika za to rešitev lahko imeli dva razloga: (1) instinktivno so pisali tako, kot je zdaj, kajti vernakularna norma je edina in tako močna v govorcih, da niso občutili »te napake« (v narekovaju), saj niso poznali standardne oblike besede; (2) to so storili namenoma, saj so $\mathrm{s}$ tem hoteli prikazati svojo lokalno identiteto, ki je najbolj povezana s kontaktno-narečno varianto maternega jezika. Zame je sprejemljiv drugi vzrok. Kljub temu bi to narečno obliko besede dala v narekovaj, saj bi ta rešitev na formali ravni zmanjšala ostrino trčenja dveh norm in bi lahko dala narečni obliki pozitivno stilistično vrednost.

6 Teorija jezikovnega menedžmenta omogoča, da lahko z njeno metodo razlikujemo dejanske probleme govorcev in jezikovne probleme, ki niso jezikovne narave, ampak človeške, ki jih ta gleda prek različnih jezikovnoideoloških in mitično popačenih optik. Pomaga, da se dihotomija pravilno - nepravilno na jezikovni ravni pretvori v kategorijo primernosti. Pripomore tudi k temu, da namesto pravilne jezikovne uporabe poudarjamo besedo moderna uporaba, da vemo, v katerih situacijah je potrebno uporabiti določeno obliko jezika. Če v konkretnih situacijah najdemo primerno besedo, potem smo z jezikom zadovoljni. Sledenje kodificirani normi ima pomen le pri določeni jezikovni uporabi. V vseh drugih situacijah je potrebno vzpodbujati govorce pri njihovem najbolj primernem, naravnem govoru. To je ena izmed najpomembnejših smernic procesa Palást. 


\section{LITERATURA}

Ágnes DOMONKOSI, István LANSTYÁK, Ildikó POSGAY (ur.), 2007: Mühelytanulmányok a nyelvmüvelésröl. Dunaszerdahely. Budapest: Gramma Nyelvi Iroda

- Tinta Könyvkiadó.

Joshua A. FISHMAN, 1974/1998: Nyelvi modernizáció és nyelvi tervezés a nemzeti modernizáció és tervezés más típusaival összehasonlítva. Nyelvi tervezés. Tanulmánygyüjtemény. Ur. Gábor Tolcsvai Nagy. Budapest: Universitas Kiadó. 31-50.

Einar HAUGEN, 1966/1998: Nyelvészet és nyelvi tervezés. Nyelvi tervezés. Tanulmánygyüjtemény. Ur. Gábor Tolcsvai Nagy. Budapest: Universitas Kiadó. 11-29.

Laura HORVAT, 2001: (Kontaktus)nyelv-használat a lendvai Kétnyelvü Középiskola diákjai körében. Szakdolgozat. Maribor.

Björn H. JERNUDD, 1993: Language planning from a management perspective: An interpretation of findings. Language conflict and language planning. Ur. Ernst Håkon Jahr. Berlin: Mouton de Gruyter. 133-142.

B. H. JERNUDD and J. V. NEUSTUPNÝ, 1987: Language planning: for whom? Proceedings of the International Colloquium on Language Planning. Ed. by L. Laforge. Québec. 71-84.

Anna KOLLÁTH, 2005: Magyarul a Muravidéken. Maribor: Slavistično društvo Maribor. (Zora 39).

- -, 2006: Detrianonizacija madžarskega jezika - izzivi in možnosti v tretjem tisočletju v osrčju Evrope. Jezik in slovstvo 51/3-4, 85-102.

Anna KOLLÁTH, István LANSTYÁK, 2007: Nyelvi probléma. Nyelvek és nyelvváltozatok. I-II. Ur. Attila Benő, Emese Fazakas, Sándor Szilágyi N. Kolozsvár. 471-493.

Miklós KONTRA, 2006: A magyar lingvicizmus és ami körülveszi. Elmélkedések népekröl, nyelvekröl és a profán medvéröl. Írások Bakró-Nagy Marianne tiszteletére. Ur. Katalin Sipőcz, Sándor Szeverényi. Szeged: Szegedi Tudományegyetem, Finnugor Nyelvtudományi Tanszék. 83-106.

István LANSTYÁK, 2000: A magyar nyelv Szlovákiában. Budapest-Pozsony: Osiris Kiadó-Kalligram Könyvkiadó-MTA Kisebbségkutató Műhely.

--, 2007: A nyelvhelyesség mint nyelvi probléma. Kisebbségkutatás 16/2, 199-213.

István LANSTYÁK, Gizella SZABÓMIHÁLY, 2002: Magyar nyelvtervezés Szlovákiában. Pozsony: Kalligram Könyvkiadó.

Sándor MATICSÁK (ur.), 2007: Nyelv, nemzet, identitás. I. A VI. Nemzetközi Hungarológiai Kongresszus (Debrecen, 2006. augusztus 22-26.) nyelvészeti előadásai. Debrecen-Budapest: Nemzetközi magyarságtudományi Társaság.

Ádám NÁDASDY, 2002: Mi a baj a nyelvműveléssel? Népszabadság, május 18. $30-31$.

Jiří NEKVAPIL, 2000: Language Management in a Changing Society. Sociolinguistic Remarks from the Czech Republic. Die sprachliche Situation. Ed. B. Panzer. 
János PÉNTEK, 2003: Státus, presztízs, attitűd és a kisebbségi nyelvváltozatok értékelése. János Péntek, Attila Benő: Nyelvi kapcsolatok, nyelvi dominanciák az erdélyi régióban. Kolozsvár. 32-39.

Gizella SZABÓMIHÁLY, 2005: Nyelvművelés - nyelvtervezés - nyelvi menedzselés. Fórum Társadalomtudományi Szemle 7/4, 67-75.

Sándor SZILÁGYI N, 2002: A magyar nyelv a Magyarországgal szomszédos országokban. Előadás az MTA 2002. évi akadémiai közgyülésének tudományos ülésszakán (május 2., Budapest). www.mta.hu

Gábor TOLCSVAI NAGY, 2007: A magyar nyelv és nemzet értelmezhetősége a határtalanitás folyamatában. Ur. Maticsák. 171-177.

József VARGA, 2003: Írjuk, mondjuk hetésiesen! Budapest: Krúdy Gyula Irodalmi Kör.

\section{ACTIVITIES AND POSSIBILITIES FOR FORMING LANGUAGE IN THE HUNGARIAN-SPEAKING SPACE AND THE PALÁST PROCESS}

Traditional (classical, academic) language cultivation in Hungary has been a target of vocational and expert debates since the political Transition into democracy of 1990 . Several scientific interpretations and language perceptions intertwine in statements regarding language cultivation, with opinions being guided by different scientific paradigms. The unavoidability of separating and clearing relations among language shaping activities related to the Hungarian language (language cultivation, planning, management) has become evident for many experts in the so called "Palást" process, the aim of which was the clearing of theoretical and practical problems in relation to Hungarian language cultivation. The name derives from the I. Applied Linguistics Workshop (2004) organised in the Slovakian village of Palást, where methodological debate of language cultivation matters was initiated. This, and annual events organised since 2004, were joint projects of the Gramma Language Office (Dunajska Streda, Slovakia) and the Department for Language Cultivation of the Institute of Language Sciences at the Hungarian Academy of Sciences (MTA). There were also other researchers participating in them, however. I myself have been participating in the research, as a researcher/linguist of contact changes of the Hungarian language in the Pomurje region, Slovenia, working for the Faculty of Arts at the University of Maribor, Slovenia, ever since the beginning. The materials discussed in the first two workshops have appeared in print as well.

This paper intends to show the results, dilemmas, work, aspects and theoretical motivation behind the research group activities underlying language management theory (Language Management Theory; Björn H. Jernudd és Jiří V. Neustupný), with the linguistic problem being the focal point (and not language incorrectness). The objective is to uncover, analyse and solve the most inclusive range of linguistic problems in a language speaking community. The linguistic problem is everything perceived by average speakers in communication, and not problems considered to be such by experts working at elite social institutions (Ministries, Academies). It does away with practices of recent language cultivation to the extent that it considers language variations to be a natural linguistic process and by no means a deterioration of the language. It emphasises that language shaping in the language use of minorities inside the Hungarian language community is of even greater importance than in the mother country. 